\title{
The Potential of Solar Air Heating in the Turkish Industrial Sector
}

\author{
Balázs Bokor ${ }^{*}$, Hacer Akhan², Dogan Eryener², László Kajtár \\ ${ }^{1}$ Department of Building Service and Process Engineering, Faculty of Mechanical Engineering, \\ Budapest University of Technology and Economics, H-1111 Budapest, Múegyetem rkp. 3-9., Hungary \\ 2 Department of Mechanical Engineering, Faculty of Engineering, Trakya University, \\ TR-22030 Edirne, Ahmet Karadeniz Campus, Turkey \\ *Corresponding author, e-mail: bokor@epgep.bme.hu
}

Received: 21 August 2018, Accepted: 28 September 2018, Published online: 19 November 2018

\begin{abstract}
Transpired solar collector (TSC) systems are simple solutions for the preheating of ventilation air with solar energy. Their performance is a function of several environmental factors, so the climatic conditions of the location play an important role. In this paper, the effect of different climatic zones on the thermal performance of the TSC is investigated. To exclude other sources of influence, the same reference industrial building is examined in four Turkish locations (Antalya, Istanbul, Ankara and Sivas) representing different climatic conditions. RETScreen simulation is carried out for all four regions to obtain the drop of conventional heating requirement in case absorber azimuth of $0^{\circ}, 45^{\circ}$ and $90^{\circ}$. To illustrate the performance, temperature rise, heating energy savings and annual solar fraction are presented. Generally, it can be stated that a location with cold climate and high solar radiation at the same time benefits most from the use of a TSC system. A mathematical correlation has been found showing the solar fraction's dependence on solar radiation and heating degree days. Finally, simulation results have been compared to a set of measurement data from an industrial building's TSC system near Istanbul.
\end{abstract}

Keywords

solar air heating system, solar space heating, transpired solar collector, unglazed transpired collector

\section{Introduction}

Turkey is one of the world's leading countries regarding the area of solar thermal collectors installed with 4 million $\mathrm{m}^{2}$ and $7.1 \mathrm{GW}_{\text {th }}$ energy benefit [1]. However, the majority of these systems produce domestic hot water in households and not heating energy for industrial buildings. Due to production processes, quality conservation of stored goods or any other specific process inside, industrial buildings usually require mechanical ventilation. The ranspired solar collector is greatly suitable for the solar heat supply of industrial buildings reducing fossil energy use. Its simple construction makes low first costs possible and its operation remains very reliable for a long time. Transpired solar collectors have shown to reach an economic payback of between 2 and 10 years [2]. Amraoui and Aliane [3] write that "the unglazed transpired solar air collector has unparalleled advantages in the ventilation preheating area". Since 1991 several international studies have emerged investigating the thermal performance of the transpired solar collector, as the use of alternative energy sources requires optimized exploitation of the energy potential [4]. Hollick [5] presented initial measurement results on a $5 \mathrm{~m}^{2}$ test stand compared with data taken from a $420 \mathrm{~m}^{2}$ solar wall of an industrial building. Later Hollick [6] reported on a large-scale solar recladding on an existing industrial building of Bombardier, near Montreal. Li et al. [7] presented a mathematical model based on energy balance equations for the performance prediction of a TSC with slit-like perforations. The model was verified with experiments under Tianjin, China climate. Eryener and Akhan [8] investigated the opportunity of integrating a capillary radiant heating system onto the back plate of the unglazed transpired collector, to supplement heating energy for conditions with low solar radiation. Later Akhan and Eryener [9] reported about the combination of a TSC with a waste heat utilization system on the production hall of an automotive company in Turkey. 
Leon and Kumar [10] built up a mathematical model for the thermal performance analysis of unglazed transpired solar collectors. The model predicts the air temperature rise and estimates the design parameters for specific hot air requirements, such as crop drying processes in tropical climates of Asia. Photovoltaic panels can be combined with transpired solar collectors creating PV-T systems. A PV panel converts only $16 \%$ of the incident solar radiation into electricity and the rest is transferred into heat, which further decreases the efficiency of the PV cell [11]. The utilization of this heat with a TSC increases both the PV efficiency and the solar fraction of the heating system.

As the above-mentioned examples show, extensive research has already been done on understanding and optimising the TSC's operational principle. However, besides structural features, the TSC's performance is strongly influenced by the climate of the actual location, as well as building type and usage. Gao et al. [12] examined the potential of glazed transpired collectors for space heating in cold climates. The glazing has been shown to be an additional factor in the collector's optical losses, but it is required if the collector is supposed to reach higher temperatures for space heating in cold climates. Al-damook and Khalil [13] evaluated the thermal performance of a self-made TSC system to understand its applicability in desert weather climates such as Iraq. TSC performance was compared with an electric heater, a fuel-fired heating system as well as a traditional solar collector. It has been found that the TSC is effective to reduce life-cycle costs and offers higher energy savings. Brown et al. [14] gave an overview of TSC installations in England and Wales, reflecting on performance influencing factors like orientation, inclination, size, colour, type of metal cladding and type of building. Kozubal et al. [15] simulated the heat delivered by TSC systems both in modular and in south wall-mounted installations for nine US-cities in different climate zones. Brown [16] compared several US Air Force bases to conclude which locations are more and which are less likely to benefit from TSC installations.

As Turkey can be divided into various climate zones, several researchers have investigated building related thermal systems for different locations of the country. Özkan and Onan [17] calculated the optimal insulation thickness and examined the effect of the glazing proportion of building facades for various climatic regions in Turkey. The basis of comparison was the classification of the country's climate into four different heating degree-day regions according to TS 825 Standard.
Ay and Khanlari [18] examined the TSC's applicability for Turkey in a theoretical way. Though, no comparative analysis has yet been made to reflect on the performance differences of a TSC system in different Turkish climatic zones. The aim of this paper is to fill this lack in the literature on the example of a reference manufacturing building, reflecting on the remarkable solar air heating potential in the industrial sector at the same time.

Despite the fact that there are many TSC installations across Europe, there is a significant lack of independently tested monitoring data of TSC performance available for different sites, as mentioned by various researchers, such as Brown et al. [14] in UK and Sicre and Baumann [19] in Switzerland. The current study provides transpired solar collector researchers with yet missing information by presenting simulated results different Turkish climatic zones compared to data from the monitored TSC system of an industrial building near Istanbul. Results indicate to what extent the location influences the thermal performance of the system and so how much it reduces the energy consumption of the reference building.

\subsection{Solar Air Heating Systems of Industrial Buildings in Turkey}

Large scale solar air collectors have been available on the Turkish energy market since 2009. Since that time more than 15 installations have been built across the country, for industrial, commercial and residential buildings. Table 1 shows TSC installations on industrial buildings in Turkey.

Locations show that except for two, all industrial TSC applications have been built in the Marmara region, North-West of the country. This might be known to the fact that the Marmara region is the most industrialized one out of Turkey's seven geographical regions and has the highest population, too. The concentrated situation of all installations is another reason for investigating how such a system would perform in different Turkish climate zones. According to Horváth and Csoknyai [20] the optimal orientation of solar collectors is south and the optimal tilt angle is assumed to be approximately $45^{\circ}$ in the Central and Eastern European region. The existing TSC systems are all installed vertically and they are mostly South-oriented, apart from a few solutions when the buildings' architectural features do not make possible a clearly equatorial orientation. In these cases the absorber surface faces the South-West or South-East. This makes it necessary to examine the change in performance when there is a change in the TSC's orientation: in the present 
Table 1 TSC installations on industrial buildings in Turkey

\begin{tabular}{llcccc}
\hline$\#$ & Location & $\begin{array}{c}\text { Area } \\
{\left[\mathrm{m}^{2}\right]}\end{array}$ & $\begin{array}{c}\text { Orientation } \\
{[-]}\end{array}$ & $\begin{array}{c}\text { Air flow } \\
{\left[\mathrm{m}^{3} / \mathrm{h}\right]}\end{array}$ & Building type \\
\hline 1 & Çayrrova & 770 & $\mathrm{~S}$ & 63720 & automotive industry \\
2 & Çayırova & 800 & $\mathrm{SW}$ & 84000 & automotive industry \\
3 & Gebze & 200 & $\mathrm{~S}$ & 30000 & production of control systems \\
4 & Dilovasi & 1040 & SE, SW & 108000 & production of electric products \\
5 & Hendek & 100 & $\mathrm{~S}$ & 7500 & automotive industry \\
6 & Bursa & 310 & $\mathrm{~S}$ & 35000 & automotive industry \\
7 & Gebze & 100 & $\mathrm{SE}$ & 15000 & chemical industry \\
8 & Istanbul & 400 & $\mathrm{~S}$ & 37500 & production of weaponry \\
9 & Dilovasi & 400 & $\mathrm{~S}$ & 70000 & chemical industry \\
10 & Dilovasi & 100 & $\mathrm{~S}$ & 7500 & chemical industry \\
11 & Çerkezköy & 2100 & $\mathrm{SE}, \mathrm{SW}$ & 252000 & production of machine elements \\
12 & Ankara & 360 & $\mathrm{~S}$ & 40000 & aerospace industry \\
13 & Adana & 400 & $\mathrm{~S}$ & 57600 & chemical industry \\
14 & Kocaeli & 400 & $\mathrm{~S}$ & 72000 & electric industry \\
\hline
\end{tabular}

performance assessment, values have been calculated for azimuth $0^{\circ}, 45^{\circ}$ and $90^{\circ}$.

\section{Operational Principle of the Transpired Solar \\ Collector}

The transpired solar collector is a perforated metallic (mainly steel or aluminium) absorber plate which is fixed onto a building's façade in $15-20 \mathrm{~cm}$ distance, creating an air gap. The air gap is sealed from all sides, so air can enter it only through the perforations. Under solar radiation the absorber gets heated up, a thin layer of warm air builds on its outer surface, which is being sucked in through the perforations as Fig. 1 shows. The air rises in the air gap to fans or air handling units, and finally the solar-heated outdoor air enters the building's air duct network. The solar heated air can be distributed in the indoor environment, e.g. as described by Both and Szánthó [21].

Even though the construction of the system is simple, it is crucially important to design, install and manufacture the TSC tailor-made for the actual building in order to achieve efficient operation and low economic payback.

Besides ventilation air heating the transpired solar collector also recaptures approx. $50 \%$ [22] of the wall structure's transmission heat losses of the surface where it is built on.

In summer, when no air heating is needed, the TSC can be bypassed in order to supply the ventilation system with fresh air directly from the exterior. Although the absorber remains hot in sunny weather, the TSC does not increase

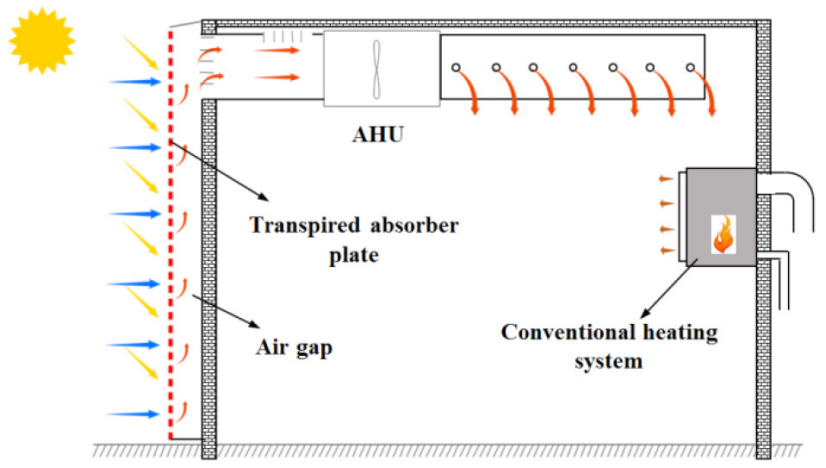

Fig. 1 Build-up and operational principle of the transpired solar collector for industrial buildings

the cooling load of the building. A natural airflow driven by buoyancy force comes to be through the perforations and in the air gap, thermally decoupling the hot absorber from the building envelope [23].

\section{Methodology of the Performance Assessment \\ 3.1 Definition of a Reference Building}

A reference building in Fig. 2 has been introduced which can be considered as a typical industrial building in Turkey. On its south-facing façade an $800 \mathrm{~m}^{2}(80 \mathrm{~m} \times 10 \mathrm{~m})$ transpired solar collector is installed, the benefit of which is being discussed. The interior of the building is one large space.

For indoor set temperature $19{ }^{\circ} \mathrm{C}$ has been considered, which is typical for industrial buildings in Turkey. It is assumed that the building's total heating requirement 


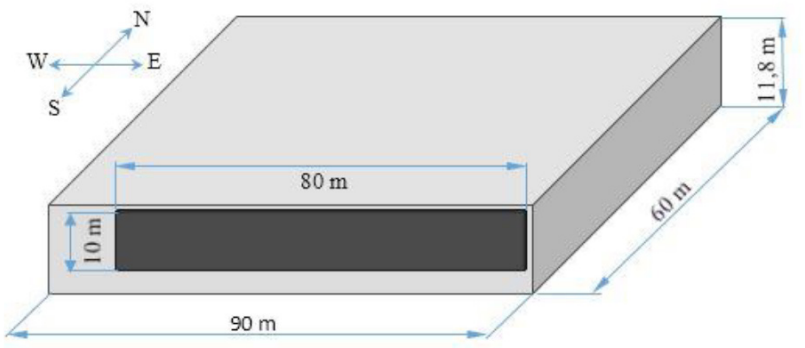

Fig. 2 Features of reference industrial building and its TSC system

is provided by air heating which is a common method for Turkish industrial buildings. The thermal characteristics of the building envelope have been defined by thermal resistance values for external walls and the roof. The chosen values are characteristic of Turkish industrial buildings. Further properties of the reference building and the TSC system are detailed in Table 2. The air change rate is assumed to be 1 per hour, hence the flow rate has been defined as $63720 \mathrm{~m}^{3} / \mathrm{h}$ across $800 \mathrm{~m}^{2}$ collector area, which equals approx. $80 \mathrm{~m}^{3} /\left(\mathrm{h} \cdot \mathrm{m}^{2}\right)$ that is a typical medium-flow operation of the TSC. The TSC's absorptivity is defined as 0.92 which is a regular value of commercially available TSC absorbers. The collector's surface is considered to be vertically mounted on the building's façade, as is most common for TSC systems. As clearly south-facing facades are not always available, TSC performance has been calculated for different azimuth degrees. Azimuth of $0{ }^{\circ}$ stands for south facing absorber, $45^{\circ}$ for south-east or south-west, whereas $90^{\circ}$ means clearly east or west facing absorber surface.

\subsection{Calculation of Heating Energy Demand}

The heating energy demand of the reference building has been determined according to Turkish Standard TS 825 [24], which lays down rules for building heat loss calculation and defines heating requirement limits for four different climate zones in Turkey. The annual heating requirement of a building $\left(Q_{H \text {, апnиаa }}[\mathrm{kWh}]\right)$ equals the sum of monthly heating requirement $\left(Q_{H, \text { monthly }}[\mathrm{kWh}]\right)$ values.

$Q_{H, \text { annual }}=\sum Q_{H, \text { monthly }}$

Monthly heating energy demand can be calculated in the knowledge of the heat loss coefficient of the building, internal and solar gain and the usage factor for gains, using monthly average values.

$Q_{H, \text { month }}=\left[H\left(t_{i}-t_{o}\right)-\gamma\left(\phi_{i, m}-\phi_{s, m}\right)\right] \cdot \tau$

with $H$ the heat loss coefficient in $[\mathrm{W} / \mathrm{K}], t_{i}$ the indoor temperature in $\left[{ }^{\circ} \mathrm{C}\right]$, to the outdoor temperature in $\left[{ }^{\circ} \mathrm{C}\right], \gamma$
Table 2 Properties of the reference building and its TSC system

\begin{tabular}{lcc}
\hline Building Features & Value & Unit \\
\hline Building width & 90 & {$[\mathrm{~m}]$} \\
Building length & 60 & {$[\mathrm{~m}]$} \\
Building height & 11.8 & {$[\mathrm{~m}]$} \\
R-value-roof & 2 & {$\left[\left(\mathrm{~m}^{2} \cdot \mathrm{K}\right) / \mathrm{W}\right]$} \\
R-value-wall & 1.5 & {$\left[\left(\mathrm{~m}^{2} \cdot \mathrm{K}\right) / \mathrm{W}\right]$} \\
Indoor set temperature & 19 & {$\left[{ }^{\circ} \mathrm{C}\right]$} \\
Solar collector absorptivity & 0.92 & {$[-]$} \\
Operation schedule & $6 / 10$ & {$[$ days $/$ hours $]$} \\
\hline
\end{tabular}

the monthly utilization factor for gains [1], $\phi_{i}$ the monthly average internal gains in [W], $\phi_{s, m}$ the monthly average solar gains in [W] and $\tau$ the time in [s].

The total heat loss coefficient is a sum of the transmission and ventilation heat loss coefficients. It attributes the thermal quality of the building envelope and the heat loss due to air exchange in the building.

$H=H_{T}+H_{V}$

with $H_{T}$ the transmission heat loss coefficient in $[\mathrm{W} / \mathrm{K}]$ and $H_{V}$ the ventilation heat loss coefficient in [W/K].

As the reference building is considered to be one open space, the transmission heat loss coefficient represents heat flow from the interior to the exterior through the building envelope and the heat loss from the interior to the ground.

$H_{T}=H_{e x t}+H_{\text {grnd }}$

The ventilation heat loss coefficient is function of the volume flow of the ventilated air ( $\dot{V}_{\text {air }}$ in $\left.\left[\mathrm{m}^{3} / \mathrm{s}\right]\right)$.

$H_{V}=\dot{V}_{\text {air }} \cdot \rho_{\text {air }} \cdot c_{p, a i r}$

with $\rho_{\text {air }}$ the density of air in $\left[\mathrm{kg} / \mathrm{m}^{3}\right]$ and $], c_{p, \text { air }}$ the specific heat capacity of air in $[\mathrm{J} / \mathrm{kg} \cdot \mathrm{K}]$.

In the case of the reference building the mechanically ventilated airflow is much more than the filtration airflow would be, thus the latter can be neglected.

\subsection{TSC Performance Evaluation}

The basis of TSC performance evaluation was building simulation using RETScreen Solar Air Heating Project Model. RETScreen is a calculation tool developed by Natural Resources Canada in 1996 and it is currently the best practice for sizing transpired solar air collector systems. For chosen locations NASA surface meteorology and solar energy weather data are available for the simulation. 
Energy savings are calculated on a monthly average time step as a sum of active absorber solar gain and wall heat recapture. RETScreen has been previously used to assess energy performance and feasibility of several TSC and other solar energy systems in different studies [25-32].

Fig. 3 shows the flowchart of the procedure carried out in order to determine the performance of the reference TSC system. Starting task is the calculation of the heating energy requirement of the model building based on TS 825 standard, alongside with the necessary fresh air demand and the air change ratio. In the knowledge of these, the TSC area can be sized using RETScreen. The TSC performance is assessed and the effects of solar radiation, TSC surface orientation, heating degree days and heating requirement are examined. Depending on these three factors, the annual solar yield is calculated and the effects are discussed respectively. The accuracy of the calculation procedure is backed up by the comparison with long-term monitored data from the TSC system of an industrial building near Istanbul. Finally, a general correlation is determined for the solar fraction with the use of the modified Shephard algorithm.

\subsection{Examined Climate Regions in Turkey}

Fig. 4(a) shows the heating degree day map of Turkey, on which four major cities are marked (Antalya, Istanbul, Ankara and Sivas), corresponding the four different climate zones given in TS 825. Fig. 4(b) shows the solar radiation map of Turkey with the examined cities marked. Heating degree days and annual sum of solar radiation values are to be compared for the examined locations, as these two parameters fundamentally influence the yearly benefits of the TSC system. The higher the heating degree days are the more heating energy is demanded, which widens yearly usage period of the TSC. At the same time, high solar radiation is to provide renewable energy. Antalya (Region 1) is in the Mediterranean region, where temperatures can reach the highest values in the country. The summer is hot, moderately dry, whereas the winter is short and mild. This can be seen on the low number of heating degree days. Istanbul's (Region 2) has a moderate climate influenced by several other climate zones. It features characteristics of the Mediterranean, humid subtropical and oceanic climate zones. This results in colder winters than in other cities in the Mediterranean Basin, temperatures can drop below zero. Ankara (Region 3) has steppe climate with its location on the Anatolian Plateau. Continental characteristics result in hot summers, but

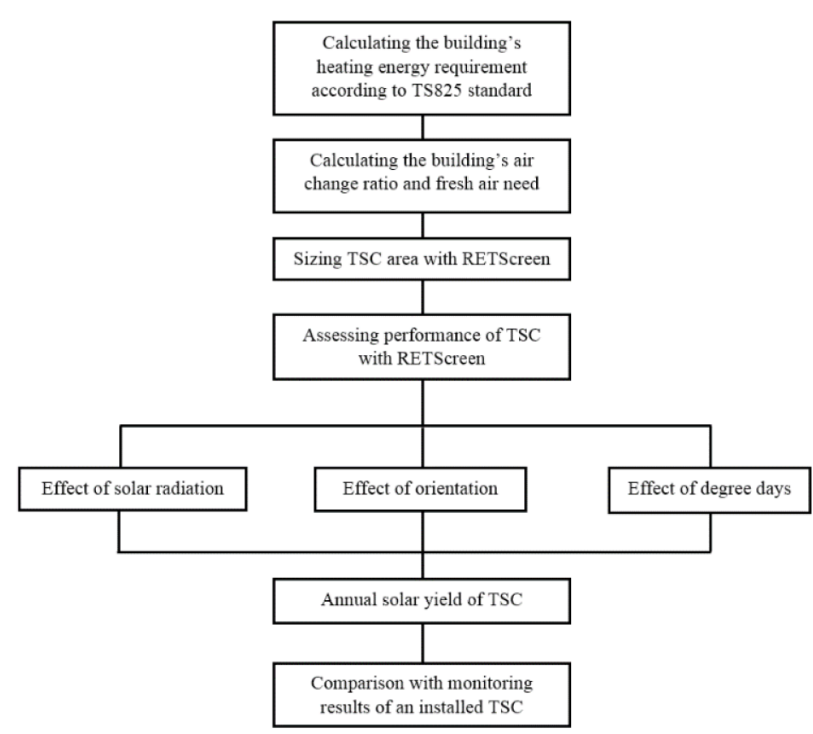

Fig. 3 Flowchart of the performance evaluation

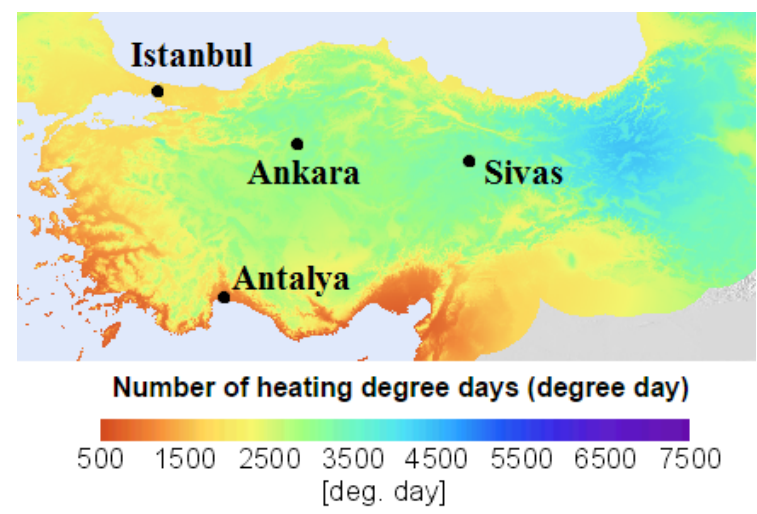

(a)

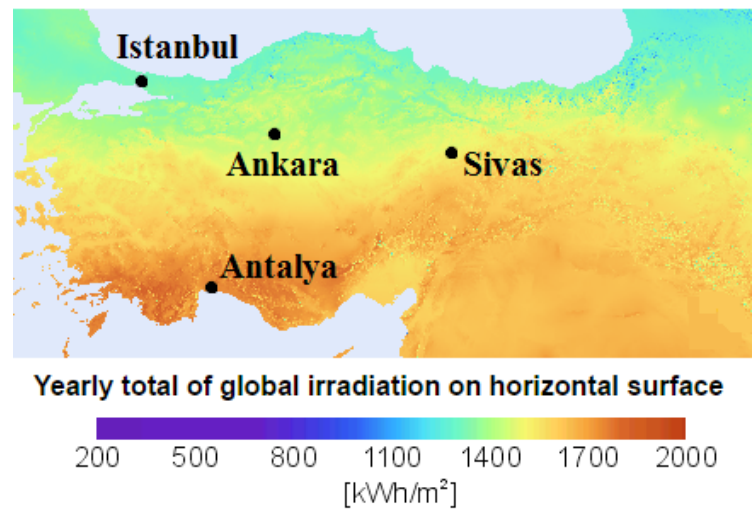

(b)

Fig. 4 (a) Examined locations on the HDD map of Turkey; (b) Map of yearly total of global irradiation on horizontal surface in Turkey [33]

due to its high elevation, the Turkish capital has cold, snowy winters. Sivas (Region 4) represents dry-summer continental climate, where the long winter's temperatures can reach even colder values than in Ankara [34]. Heating degree days are the highest in Sivas out of the four 
examined cities. Antalya receives the highest and Istanbul the lowest amount of solar radiation. Ankara and Sivas have colder climate than Istanbul, yet they have a remarkably higher annual sum of solar radiation.

\section{Results and discussion}

The effect of the TSC on the reference building's conventional heating energy consumption can be seen in Fig. 5 . Four columns belong to each month presenting heating requirement values without solar air heating $(\mathrm{SAH})$, and with SAH when the azimuth of the collector surface is $0^{\circ}$, $45^{\circ}$ and $90^{\circ}$. Generally, one can observe that the highest savings can be reached when the collector's azimuth is $0^{\circ}$, followed by $45^{\circ}$ and $90^{\circ}$.

The effect of a TSC system in the examined climate zones of Turkey has been summarized in Table 3. Total

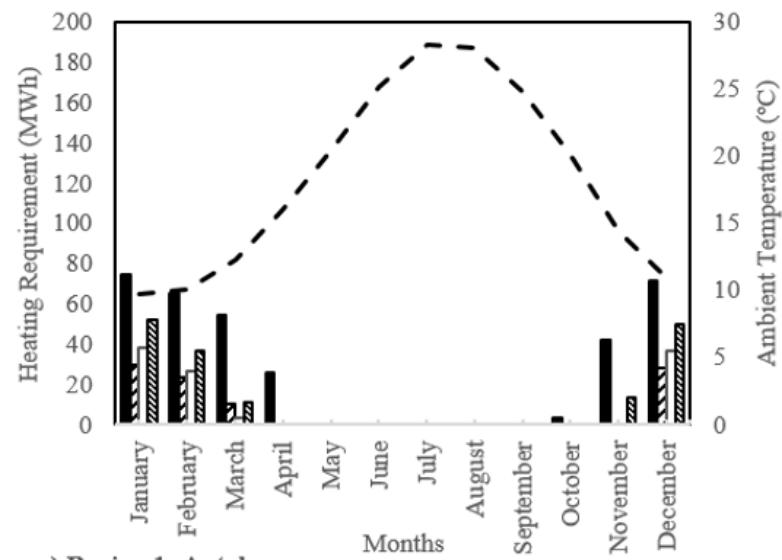

a) Region 1- Antalya

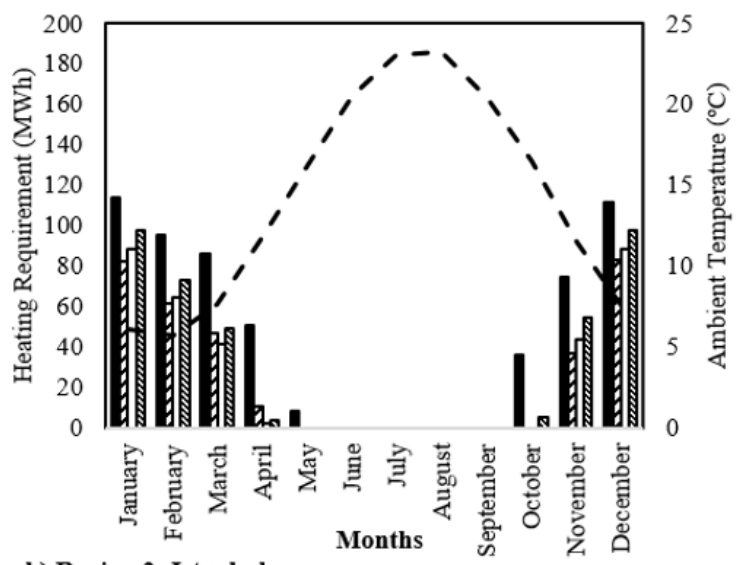

b) Region 2- Istanbul heating degree days show that the most heating energy is consumed by the reference industrial building is in Sivas, followed by Ankara, Istanbul and Antalya, respectively. Sivas reaches the highest temperature rises, followed by Ankara, Antalya and Istanbul.

The solar fraction is the highest at an azimuth of $0^{\circ}$ and it decreases with rising azimuth. The extent of the decrease is different for the four locations. The solar fraction of the system in Antalya drops to highest extent if the deviation from south grows, followed by Ankara, Istanbul and Sivas. Annual energy savings by the use of the TSC have been calculated for a collector area of one $\mathrm{m}^{2}$. In all cases the south-facing collector saves the most energy and savings lower in a lesser extend from azimuth $0^{\circ}$ to $45^{\circ}$ than from azimuth $45^{\circ}$ to $90^{\circ}$. This means that smaller deviation from south does not worsen the performance
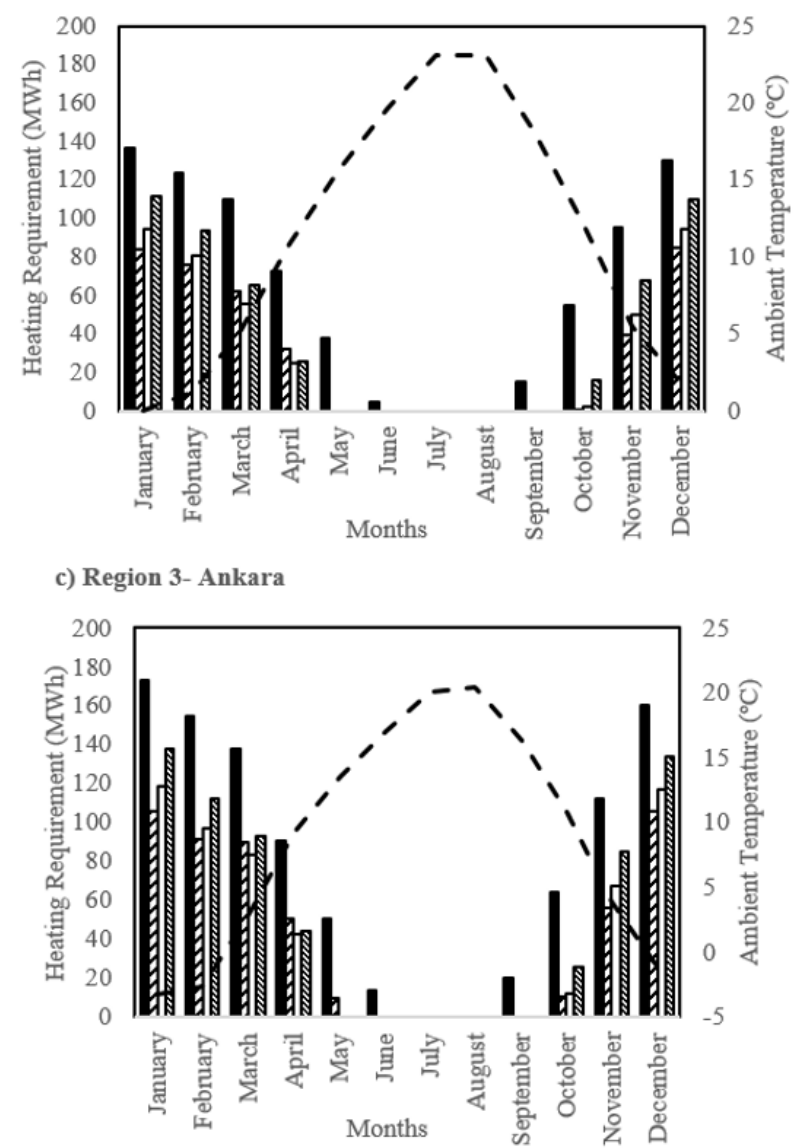

d) Region 4- Sivas

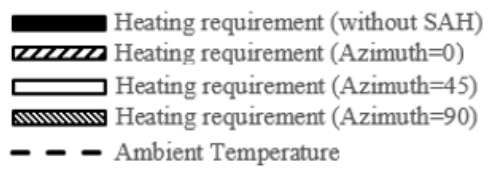

Fig. 5 Heating requirement (with conventional heating system) for industrial building without SAH and with SAH system for different azimuth values in four climatic zones in Turkey 
Table 3 Heating degree days, average winter temperature rise, annual solar fraction, annual energy savings for different azimuth values in four climatic zones in Turkey

\begin{tabular}{|c|c|c|c|c|}
\hline & Antalya & Istanbul & Ankara & Sivas \\
\hline HDD & 1043 & 1846 & 2763 & 3431 \\
\hline \multicolumn{5}{|c|}{ Temperature Rise (average) $[\mathrm{K}]$} \\
\hline $0^{\circ}$ & 8.44 & 7.54 & 8.87 & 12.85 \\
\hline $45^{\circ}$ & 10.77 & 9.54 & 10.92 & 11.78 \\
\hline $90^{\circ}$ & 12.38 & 11.61 & 12.85 & 14.00 \\
\hline \multicolumn{5}{|c|}{ Annual solar fraction } \\
\hline $0^{\circ}$ & $72.9 \%$ & $44.6 \%$ & $51.8 \%$ & $46.9 \%$ \\
\hline $45^{\circ}$ & $68.9 \%$ & $42.8 \%$ & $48.6 \%$ & $45.0 \%$ \\
\hline $90^{\circ}$ & $51.7 \%$ & $33.8 \%$ & $37.4 \%$ & $35.5 \%$ \\
\hline \multicolumn{5}{|c|}{ Energy savings $[\mathrm{kWh} /(\mathrm{m} 2 \cdot \mathrm{a})]$} \\
\hline $0^{\circ}$ & 308 & 321 & 504 & 573 \\
\hline $45^{\circ}$ & 291 & 309 & 472 & 549 \\
\hline $90^{\circ}$ & 219 & 243 & 363 & 434 \\
\hline
\end{tabular}

very much, but one degree of change has a higher impact on the performance as the azimuth gets closer to $90^{\circ}$. Considering the cities, the highest savings are reached in Sivas, then in Ankara, Istanbul and Antalya.

For the exact definition of the correlation between solar fraction depending on heating degree days and solar radiation, Renka's modified quadratic Shepard algorithm for three-dimensional data has been used [35]. The modified quadratic Shepard's method is one of the most powerful algorithms for the multivariate interpolation of scattered data sets. Shepard algorithm has been efficiently implemented and Eq. (6) has been found for the relation between solar fraction, heating degree days and solar radiation from RETScreen simulated data:

$$
\begin{aligned}
S F= & a_{1}+a_{2} \cdot S R+a_{3} \cdot H D D+a_{4} \cdot S R^{2} \\
& +a_{5} \cdot H D D^{2}+a_{6} \cdot S R \cdot H D D
\end{aligned}
$$

with $S F$ the solar fraction in [1], $S R$ the intensity of solar radiation in $\left[\mathrm{kWh} /\left(\mathrm{m}^{2} \mathrm{~d}\right)\right]$ and $H D D$ the number of heating degree days in $\left[{ }^{\circ} \mathrm{C} \cdot \mathrm{d}\right]$.

The parameters of Eq. (6) are given in Table 4.

The diagram in Fig. 6 is the graphical depiction of the obtained function for three realistic intensities of solar radiation on vertical surface. Results show that depending in solar radiation the solar fraction has a minimum at a certain value of $H D D$. For locations with lower heating degree days the solar fraction is high, as the solar heat produced by the TSC takes out a vast amount of the practically low heating requirement. The increase of the solar fraction with growing heating degree days can be explained with

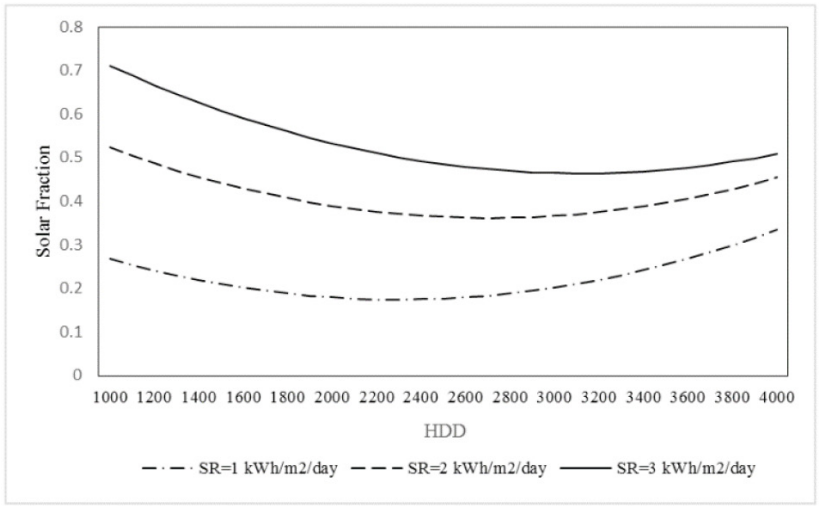

Fig. 6 TSC solar fraction of the reference building's heating system as a function of heating degree days, for three different intensities of solar radiation

\begin{tabular}{cc}
\multicolumn{2}{c}{ Table 4 Coefficients for the regression } \\
\hline $\mathrm{a}_{1}$ & 0.1015887301 \\
$\mathrm{a}_{2}$ & 0.3994630884 \\
$\mathrm{a}_{3}$ & -0.0002101574821 \\
$\mathrm{a}_{4}$ & -0.03320312681 \\
$\mathrm{a}_{5}$ & $5.549925348 \mathrm{E}-008$ \\
$\mathrm{a}_{6}$ & $-4.501181896 \mathrm{E}-005$ \\
\hline
\end{tabular}

the solar heat of the TSC being utilized in higher proportion in colder locations, where the actual need for solar heat is much more likely at the time when it comes to be.

Fig. 7 shows the annual specific space heating demand for the reference building in the four examined climatic zones. Columns show that the highest reduction of heating energy demand on a yearly basis can be obtained with 


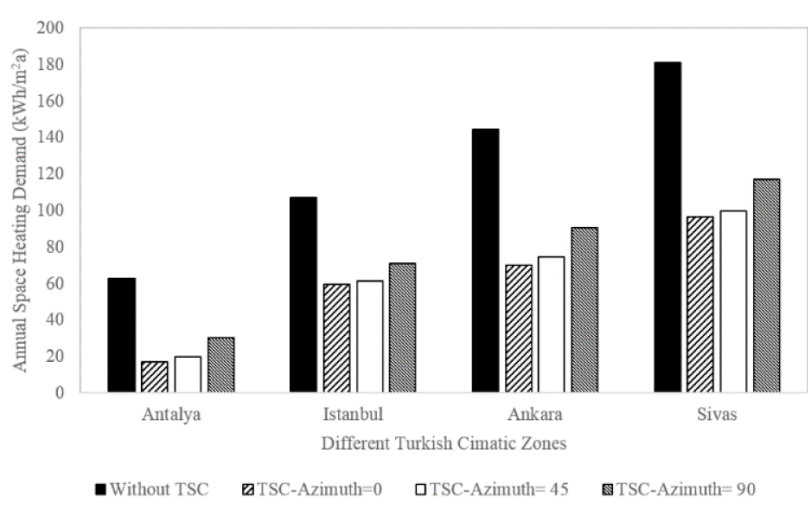

Fig. 7 Reduction of annual specific space heating demand by TSC with different azimuth in four climatic zones of Turkey

a clearly south-facing TSC. Furthermore, the differences between the energy consumption at azimuth values of $0^{\circ}$, $45^{\circ}$ and $90^{\circ}$ show that there is only a minor drop of yearly performance if the TSC's orientation is changed under $45^{\circ}$ of azimuth, but the deterioration rises between $45^{\circ}$ and $90^{\circ}$. It is to be underlined that Fig. 7 shows annual values of specific space heating demand in which the lowest values are obtained with azimuth $=0{ }^{\circ}$, followed by $45^{\circ}$ and $90^{\circ}$. This sequence in yearly values is important, because as Fig. 5 shows, the sequence of heating requirement among the three azimuth values can be different for certain months.

\section{Comparison of simulated and monitored TSC performance}

To see the accuracy of the predictions, simulated results for Istanbul have been compared to measurement data recorded on the TSC system of an automotive industrial building in Çayırova, near Istanbul. Measurement data is available from December 2012, February - April 2013 and December 2013 - March 2014. In Table 5 heating degree day and solar radiation values, TSC primary energy savings as well as the air's average temperature rise on the TSC are presented for both the reference and the measured building, for comparison. Note that the solar radiation values here are considered for one $\mathrm{m}^{2}$ vertically installed TSC area with the azimuth of $0^{\circ}$.

Results show that the model predicts primary energy savings and air temperature rise accurately. For February, March, April and December 2013, as well as January and February 2014 measured values of PE savings and air temperature rise correlate with the simulated results. Minor deviations are due to the higher or lower $H D D$ and $S R$ of the actual month than the monthly average. In December 2012 the higher savings and temperature rise may be a result of air by-passing from the measured building's interior into its supply air stream. This results in a smaller amount of air taken from the TSC in reality, whereas the simulation model considers the complete supply air stream being preheated by the TSC. For March 2014 the lower savings and temperature rise are a result of the building specific operation of the measured system, as well as lower $H D D$ values than average.

\section{Conclusion}

Generally, high solar radiation and high number of heating degree days enable the TSC system to deliver its maximum possible thermal performance. In Antalya the solar radiation is high, but the system cannot reach as high energy savings as in Ankara and Sivas, because the heating period is much shorter. In Istanbul the humid and mild climate results in the lowest average solar radiation of the examined locations, with relatively low heating degree days. The system in Sivas pays itself off the most quickly. Regardless of climatic conditions, it is important to minimize the deviation of the absorber surface from the South, as predicted benefits always dropped with higher azimuth values.

Table 5 Comparison of calculated and measured data

\begin{tabular}{|c|c|c|c|c|}
\hline & RETScreen Results & & Monitored Results & \\
\hline & Ref. building & 2012 & 2013 & 2014 \\
\hline & $\begin{array}{c}\text { HDD / SR / PE savings } \\
\text { / } \Delta \text { Tair }\end{array}$ & $\begin{array}{c}\mathrm{HDD} / \mathrm{SR} / \text { PE savings } \\
\text { / } \Delta \text { Tair }\end{array}$ & $\begin{array}{c}\text { HDD / SR / PE savings } \\
\text { / } \Delta \text { Tair }\end{array}$ & $\begin{array}{c}\text { HDD / SR / PE savings } \\
\text { / } \Delta \text { Tair }\end{array}$ \\
\hline & $\begin{array}{c}{\left[{ }^{\circ} \mathrm{C} \cdot \text { days } / \mathrm{kWh} /\right.} \\
\mathrm{m} 2, \text { month / MWh / K] }\end{array}$ & $\begin{array}{c}{\left[{ }^{\circ} \mathrm{C} \cdot \text { days } / \mathrm{kWh} /\right.} \\
\mathrm{m} 2, \mathrm{month} / \mathrm{MWh} / \mathrm{K}]\end{array}$ & $\begin{array}{c}{\left[{ }^{\circ} \mathrm{C} \cdot \text { days } / \mathrm{kWh} /\right.} \\
\mathrm{m} 2, \mathrm{month} / \mathrm{MWh} / \mathrm{K}]\end{array}$ & $\begin{array}{c}{\left[{ }^{\circ} \mathrm{C} \cdot \text { days } / \mathrm{kWh} /\right.} \\
\mathrm{m} 2, \mathrm{month} / \mathrm{MWh} / \mathrm{K}]\end{array}$ \\
\hline Jan. & $370 / 64.0 / 31.86 / 5.99$ & - & - & $298 / 71.1 / 37.98 / 5.16$ \\
\hline Feb. & 345 / 70.6 / $34.21 / 6.55$ & - & $293 / 61.0 / 41.22 / 6.60$ & $275 / 75.7 / 31.30 / 5.34$ \\
\hline Mar. & 324 / 92.9 / $39.50 / 6.72$ & - & $280 / 91.4 / 35.79 / 5.80$ & $262 / 95.3 / 19.84 / 2.81$ \\
\hline Apr. & 187 / 89.7 / $40.31 / 7.26$ & - & $177 / 82.0 / 39.26 / 5.88$ & - \\
\hline Dec. & $321 / 56.6 / 28.81 / 5.49$ & $268 / 85.3 / 50.26 / 9.11$ & $338 / 77.1 / 45.07 / 5.89$ & - \\
\hline
\end{tabular}


Finally, the simulated results of the reference building in Istanbul have been compared to a set of measurement data from an industrial building's TSC system operating in Cayirova, near Istanbul. Results of comparison show that the simulation predicts the thermal performance of the TSC accurately, as the simulated and measured values correlate in almost every measured month.

\section{References}

[1] Eryener, D., Akhan, H. "The Performance of First Transpired Solar Collector Installation in Turkey", Energy Procedia, 91, pp. 442-449, 2016.

https://doi.org/10.1016/j.egypro.2016.06.172

[2] Hall, R., Wang, X., Ogden, R., Elghali, L. "Transpired Solar Collectors for Ventilation Air Heating" Proceedings of the Institution of Civil Engineers - Energy, 164(3), pp. 101-110, 2011. https://doi.org/10.1680/ener.2011.164.3.101

[3] Amraoui, M. A., Aliane, K. "Three-dimensional Analysis of Air Flow in a Flat Plate Solar Collector", Periodica Polytechnica Mechanical Engineering, 62(2), pp. 126-135, 2018.

https://doi.org/10.3311/PPme.11255

[4] Takács, J. "Possibility of Geothermal Water's Using in Geothermal Energy Systems", Periodica Polytechnica Mechanical Engineering, 61(4), pp. 272-275, 2017.

https://doi.org/10.3311/PPme.10546

[5] Hollick, J. C. "Unglazed solar wall air heaters", Renewable Energy, 5(1-4), pp. 415-421, 1994 https://doi.org/10.1016/0960-1481(94)90408-1

[6] Hollick, J. C. "World's largest and tallest solar recladding", Renewable Energy, 9(1-4), pp. 703-707, 1996. https://doi.org/10.1016/0960-1481(96)88382-0

[7] Li, B., You, S., Ye, T., Zhang, H., Li, X., Li, C. " Mathematical modeling and experimental verification of vacuum glazed transpired solar collector with slit-like perforations", Renewable Energy, 69, pp. 43-49, 2014.

https://doi.org/10.1016/j.renene.2014.02.054

[8] Eryener, D., Akhan, H. "Theoretical and Experimental Investigation of Perforated Solar Air Collector Coupled to a Capillary Radiant Heating System", In: 9th International Conference on Heat Transfer Fluid Mechanics and Thermodynamics, Malta, 2012, pp. 1547-1552.

[9] Akhan, H., Eryener, D. "Building integrated solar air heating with waste heat utilization", Energy Conversion and Management, 157, pp. 136-145, 2018. https://doi.org/10.1016/j.enconman.2017.12.007

[10] Leon, M. A., Kumar, S. "Mathematical modeling and thermal performance analysis of unglazed transpired solar collectors", Solar Energy, 81(1), pp. 62-75, 2007. https://doi.org/10.1016/j.solener.2006.06.017

[11] Nehari, T., Benlakam, M., Nehari, D. "Effect of Fins Length for the Passive Cooling of the Photovoltaic Panels", Periodica Polytechnica Mechanical Engineering, 60(2), pp. 89-95, 2016. https://doi.org/10.3311/PPme.8571

\section{Acknowledgement}

The international cooperation between Trakya University and Budapest University of Technology and Economics has been funded by the "National Talent Program" of the Hungarian Ministry of Human Capacities.

[12] Gao, L., Bai, H., Mao, S. "Potential application of glazed transpired collectors to space heating in cold climates", Energy Conversion and Management, 77, pp. 690-699, 2014.

https://doi.org/10.1016/j.enconman.2013.10.030

[13] Al-damook, A., Khalil, W. H. "Experimental evaluation of an unglazed solar air collector for building space heating in Iraq", Renewable Energy, 112, pp. 498-509, 2017. https://doi.org/10.1016/j.renene.2017.05.051

[14] Brown, C., Perisoglou E., Hall, R., Stevenson, V. "Transpired Solar Collector Installations in Wales and England", Energy Procedia, 48, pp. 18-27, 2014. https://doi.org/10.1016/j.egypro.2014.02.004

[15] Kozubal, E., Deru, M., Slayzak, S., Norton, P., Barker, G., McClendon, J. "Evaluating the Performance and Economics of Transpired Solar Collectors for Commercial Applications", In: 2008 ACEEE Summer Study on Energy Efficiency in Buildings, Pacific Groove, CA, USA, 2008, pp. 193-208.

[16] Brown, D. S. "An Evaluation of Solar Air Heating at United States Air Force Installations", PhD Theses, Air University, Air Force Institute of Technology, Wright-Patterson Air Force Base, Ohio, 2009.

[17] Özkan, D. B., Onan, C. "Optimization of insulation thickness for different glazing areas in buildings for various climatic regions in Turkey", Applied Energy, 88(4), pp. 1331-1342, 2011. https://doi.org/10.1016/j.apenergy.2010.10.025

[18] Ay, I., Khanlari, A. "Güneş Duvarı Sisteminin Çalışma Prensibi ve Türkiye'deki Uygulanabilirliği" (Solar Wall System Operational Principle and Applicability in Turkey), Gazi Üniversitesi Fen Bilimleri Dergisi Part: C, Tasarım Ve Teknoloj, 3(3), pp. 525-533, 2015. (in Turkish)

[19] Sicre, B., Baumann, P. "High-efficiency ventilation and heating systems by means of solar air collectors for industry building refurbishment", International Journal of Low-Carbon Technologies, 10(2), pp. 139-145, 2015. https://doi.org/10.1093/ijlct/ctv002

[20] Horváth, M., Csoknyai, T. "Evaluation of Solar Energy Calculation Methods for $45^{\circ}$ Inclined, South Facing Surface", Energy Procedia, 78, pp. 465-470, 2015. https://doi.org/10.1016/j.egypro.2015.11.700

[21] Both, B., Szánthó, Z. "Experimental and Numerical Investigation of an Offset Jet Using Tangential Air Distribution System", Periodica Polytechnica Mechanical Engineering, 60(3), pp. 129136, 2016. https://doi.org/10.3311/PPme.8017 
[22] RETScreen International Clean Energy Decision Support Centre (Canada); United Nations Environment Programme, United States National Aeronautics and Space Administration, CANMET Energy Technology Centre (Canada) "Solar Air Heating Project Analysis", In: Clean Energy Project Analysis: RETScreen Engineering \& Cases Textbook", Minister of Natural Resources Canada, 2001-2005.

[23] Bokor, B., Akhan, H., Eryener, D., Kajtár, L. "Theoretical and experimental analysis on the passive cooling effect of transpired solar collectors", Energy and Buildings, 156, pp. 109-120, 2016. https://doi.org/10.1016/j.enbuild.2017.09.063

[24] "TS Standards 825, Thermal Insulation Requirements for Buildings", Turkish Standards Institution, Ankara, Turkey, 2013.

[25] Carpenter, S., Meloche, N. "The RETScreen Model for Simulating the Performance of Solar Air Heating Systems", In: eSIM Conference, Montreal, Canada, 2002.

[26] Hall, R., Allen, A. "A new tool for assessing the performance of Transpired Solar Collectors used for solar ventilation pre-heating", Energy Procedia, 70, pp. 57-64, 2015. https://doi.org/10.1016/j.egypro.2015.02.097

[27] Tebbe, P., Moaveni, S., Schwartzkopf, L. "Final Project Report, Performance Analysis of Solar Walls in Minnesota", Minnesota State University, Mankato, MN, USA, 2011.

[28] Connolly, D., Lund, H., Mathiesen, B. V., Leahy, M. "A review of computer tools for analysing the integration of renewable energy into various energy systems", Applied Energy, 87(4), pp. 10591082, 2010.

https://doi.org/10.1016/j.apenergy.2009.09.026
[29] Lee, K.-H., Lee, D.-W., Baek, N.-Ch., Kwon, H.-M., Lee, Ch.-J. "Preliminary determination of optimal size for renewable energy resources in buildings using RETScreen", Energy, 47(1), pp. 83-96, 2012.

https://doi.org/10.1016/j.energy.2012.08.040

[30] Houri, A. "Solar water heating in Lebanon: Current status and future prospects", Renewable Energy, 31(5), pp. 663-675, 2006. https://doi.org/10.1016/j.renene.2005.08.003

[31] Almarshoud, A. F. " Performance of solar resources in Saudi Arabia", Renewable and Sustainable Energy Reviews, 66, pp. 694701, 2016. https://doi.org/10.1016/j.rser.2016.08.040

[32] Rehman, S., Bader, M. A., Al-Moallem S. A. "Cost of solar energy generated using PV panels", Renewable and Sustainable Energy Reviews, 11(8), pp. 1843-1857, 2007. https://doi.org/10.1016/j.rser.2006.03.005

[33] European Commission, Joint Research Centre "Photovoltaic Geographical Information System - Interactive maps", [online] Available at: http://re.jrc.ec.europa.eu/pvgis/apps4/pvest.php\# [Accessed: 26 December 2017]

[34] Sensoy, S. "Climate of Turkey", Turkish State Meteorological Service, [pdf] Available at: https://www.mgm.gov.tr/files/en-US/ climateofturkey.pdf. [Accessed: 17 December 2017]

[35] Renka, R. J. "Multivariate interpolation of large sets of scattered data", ACM Transactions on Mathematical Software, 14(2), pp. 139-148, 1988. https://doi.org/10.1145/45054.45055 